\title{
Stolen Product
}

National Cancer Institute

\section{Source}

National Cancer Institute. Stolen Product. NCI Thesaurus. Code C121836.

A product has been determined to have been stolen. 